\title{
ElF4A2 wt Allele
}

National Cancer Institute

\section{Source}

National Cancer Institute. EIF4A2 wt Allele. NCI Thesaurus. Code C97468.

Human EIF4A2 wild-type allele is located in the vicinity of $3 q 28$ and is approximately $7 \mathrm{~kb}$ in length. This allele, which encodes eukaryotic initiation factor 4A-II, plays a role in the positive regulation of translation. A chromosomal translocation $\mathrm{t}(3 ; 18)(\mathrm{q} 27 ; \mathrm{p} 11.2)$ of this gene and the BCL6 gene is associated with non-Hodgkin lymphoma. 